\title{
Discussion on interaction between English teaching method and the second language acquisition theory
}

\author{
Zhimei Zhao
}

\author{
AIEN International Institute, Dalian Jiaotong University, Dalian, 116021, China
}

\begin{abstract}
Keywords: The second language acquisition (SLA) theory; Krashen; English; Teaching method
\end{abstract}

\begin{abstract}
The second language acquisition (SLA) is learning content that is closely related to English teaching. In the process of colleges' English teaching, it is essential to deal with interaction between English teaching method and SLA theory and apply SLA theory to guide English classroom teaching in order to improve English application ability of college students and enhance teaching effectiveness of English classroom. This thesis elaborates SLA theory, analyzes the interaction between English teaching method and SLA theory and proposes the countermeasure that SLA theory is used to advance English teaching.

English teaching has had over 2,000 years' history and development of modern English teaching has owned more than 100 years' history. Both generation and application of English teaching method in different periods depend on social demands and teaching ideas appreciated by advocators. At the same time, the foregoing opinions reflect social development situations at that time and English teaching tracks to different degree. In the process of English teaching, the second language acquisition (SLA) theory such a new subject was born between the 1960s and the 1970s. Over more than 40 years, Research on SLA in the whole world has had significant development and brought new reform to global English teaching. However, there is little research on interaction between SLA theory and English teaching method. Thus, the author carries out profound research on this problem, hoping to have instructional effect on practice of English teaching in China.
\end{abstract}

\section{Introduction of SLA theory}

Krashen, an American linguist, put forward a brand-new language acquisition theory at the beginning of the 1970s. The theory is proposed by studying learners in the process of the second language acquisition and involves the process in which the second language learning is learned in social environment of target language on the basis that necessary mother tongue system has been mastered. Specifically, this theory is mainly composed of the following three parts: firstly, hypothesis about difference between acquisition and learning. Krashen deems that acquisition is a language learning process that is subconscious, informal and even gleaning-type, while learning is conscious, i.e., rules related to language are learned formally and clearly. Therefore, acquisition method is more important than learning method. Some SLA theory experts think that children acquire language, while adults can only learn language. However, according to the hypothesis that Krashen makes, adults may also acquire corresponding language. Secondly, input hypothesis is involved, which is mainly put forward based on difference in acquisition and learning basis. Krashen thinks input hypothesis is the most important component of his theory since it has answered the most important question in language teaching, i.e., how to acquire a language, especially a foreign language. Krashen explains input hypothesis as input hypothesis has relationship with acquisition rather than learning; brand-new language content can be acquired only by comprehending structural language that exceeds learners' current language ability a little; once communication succeeds, input can be comprehended; speaking ability will be generated naturally but cannot succeed directly. Thirdly, the theory contains affective filter hypothesis. It mainly advocates that affective factors will affect SLA directly. This concept was put forward by the linguists Dule and Burr in 1977. Affective filter factors mainly contain motivation, confidence and degree of anxiety. Affective factors can only generate obstruction or drive input to enter language learning organ in our brain. Its significance is that teaching objective should not only provide input 
that can be understood but also create an atmosphere where affective filter is quite low.

\section{Analysis of the interaction between English teaching method and SLA theory}

Any English Language Learning theory related to English teaching method involves two fields, i.e., process orientation and condition orientation. The former mainly advocates learning process, such as habituation information collection, conclusion and summarization, while the latter pays attention to thermal insulation conditions of learners, such as motivation, language competence, psychological quality and affective factors etc. The foregoing theories about language learning seriously affect development and application of English teaching method. Teaching methods like natural method, general reaction and communicative teaching method show dual elements of process orientation and condition orientation. Learners can enter real language circumstance to learn pleasantly. Club language teaching method and silence method pay more attention to condition orientation, put forward that language functions and psychological features of learners should pay more attention to process orientation and strengthen processes, such as input of language information, comprehension and communication etc. With respect to the interaction between SLA theory and English teaching method, SLA theory has important enlightenment on English teaching method. Research achievements on SLA theory will be reflected by the situation that application, theory and practice in English language teaching have interrelation from a macroscopic perspective. From a microcosmic perspective, SLA theory has enlightenment and instructive importance for teaching of all language skills.

Being guided by SLA theory, language acquisition can be divided into natural acquisition and classroom learning. In detail, classroom teaching and English teachers have direct relationship. In English teaching method, grammar-translation method mainly exists in English classroom teaching. We should enhance learning in the aspect of linguistic form consciously. In doing so, chances to have natural acquisition are fewer. The audio-lingual method should be superior to the grammar-translation method so as to provide more chances to acquire English naturally. Both the audio-lingual method and direct method can provide input of much comprehensible English language information for learners, and the general reaction method can accelerate natural acquisition potentially. Suggestion method pays much attention to mental pleasure of learners in the process of language learning and makes natural acquisition be generated indirectly. Theoretical basis of the natural method is the natural order hypothesis proposed by Krashen. Besides, natural acquisition and classroom teaching is combined reasonably and natural language communication is strengthened. Methods like communication teaching, task-based teaching and club language learning use SLA effect theory to get theoretical support and values English Language Learning method with interaction and cooperation. The communication teaching method deems that vocabulary and grammar teaching is important reflection of communicative competence. In accordance with English language acquisition theory, it is no need to teach grammar in English classroom since English language acquisition has contained acquisition in the aspects of vocabulary and grammar and target language is perceived and applied to English Language Learning constantly。

Input of English language is a key point of English learning and English language teaching and basis of development of English teaching method. We should realize English language learning and acquisition by the process, i.e., input - absorption - output. At the same time, affective factors will decide the degree to which learners accept information input of English language and situations about migration of learners to English target language culture, which also makes learners' anxiety reduce gradually in the process of English teaching. In doing so, input amount of English language will increase naturally and degree of acceptance will be higher. Once learners' anxiety degree is high, input amount of English language will be low and degree of acceptance will be low naturally. Thus, the interaction between SLA theory and English teaching method is mainly reflected by the following aspect: SLA theory can provide support in principle and theory for English teaching; and English teaching can provide enough practical chances for SLA theory and offer corresponding 
evidence to development of action research so as to obtain more scientific and more standard research achievements. For example, under enlightenment of SLA theory mode, Chinese researchers design a theoretical teaching mode about Chinese students' English learning according to features of Chinese students' English learning and achieve good effectiveness in practice.

Although SLA research cannot provide achievements that can be consulted and operated conveniently for English teaching directly, it can deepen our comprehension about English learning and English teaching practice. English teaching should be guided by SLA theory to improve quality of English classroom teaching, i.e., to make learners be immersed in the target language environment established by English teachers to carry out meaningful communicative activities, take part in communicative activities like solving problems and finishing tasks and apply research achievements about SLA to English teaching practice of China.

\section{The countermeasure that SLA theory is used to advance English teaching}

\section{(I) Creating SLA environment actively}

In countries whose mother tongue is English, learners can learn and master English knowledge rapidly. According to this, we may draw this conclusion that language learners can master a language rapidly if they usually contact with the second language environment. Thus, in the process in which English teaching is implemented, English teachers should create a good second language environment for students more actively. Main operation methods are shown as follows. Firstly, apply multi-media teaching to a larger extent. Nowadays, application of multimedia to English classroom becomes wider and wider. Consequently, English teachers must strengthen input in several forms, cultivate learners' interest and provide a second language atmosphere for them. For instance, they may ask learners to listen to English tapes and watch classical English movies to the largest extent in order to provide more idiomatic English language information for learners and cultivate learners' language sense. Secondly, develop situational performance. It can be said that situational performance is one of the important teaching methods that can improve learners' oral English communicative competence. After playing a movie, English teachers may choose some sections and ask learners to form several groups to simulate such sections, use the language knowledge they have learned to perform scenes and then implement dialogue activities.

\section{(II) Enhancing strength of diversified extracurricular input}

Reasonable extra-curricular activities are a very important supplementary part of English classroom teaching and can consolidate and expand learners' knowledge in all aspects to the largest extent and help learners develop their own communicative competence practically. English teachers should provide more language input for learners after class, such as English corner and English salon etc., to promote learners to accept input more actively and more positively, achieve better teaching effectiveness and strengthen English language acquisition. English teachers should guide learners to read more English newspaper, listen to more English broadcast and watch more English movies in a planned way with emphasis to become familiar with knowledge in the aspect of cultural background. Besides, teachers ought to encourage learners to communicate with foreign teachers in many aspects and organize learners to take part in various English activities as much as possible to improve their ability to apply English language practically.

\section{(III) Improving quality and quantity of the second language input}

In the process of previous English teaching, content input mainly adopts teacher-directed teaching method. However, the method does not get significant effectiveness since input of new information cannot make learners master the language practically. Thus, we advocate a new teaching method where learners act as subjects and more flexible methods should be applied to content input in combination with related scenes for multi-channel input. In teaching, teachers may make full use of multimedia teaching method to offer learners a new-type language environment that integrates effect of several senses like sound, image and video. Then, teachers can arouse their learning motivation and enthusiasm for knowledge as well as make classroom teaching realize the most ideal input effectiveness. 
(IV) Applying affective factors to cultivate learning interest in the second language

According to the affective filter hypothesis of Krashen, affective factors mainly contain people's interest, motivation, confidence and anxiety. Comprehensible input can be realized only when affective filter is low. Since English teaching has not treated SLA as main orientation, i.e., it has not treated communication as a main teaching objective all the time, learners can neither enjoy pleasure brought by language communication in English learning nor establish clear learning motivation. This requires that English teachers should change their ideas actively, pay attention to input of affective factors, apply active and vivid teaching methods, form more relaxing and more pleasant input environment, arouse learners' learning motivation and improve their learning enthusiasm. Teachers should not spend much time in correcting learners' grammar errors in expression but pay attention to specific connotation of expression to reduce learners' anxiety. Additionally, teachers should not consider teaching schedule and fluency only but suit the remedy to the case according to learners’ specific situations.

\section{Conclusion}

To sum up, SLA theory provides brand-new concept for English teaching and thus brand-new reform of English teaching method is caused. English teaching method must follow language acquisition law, be based on national conditions of China, apply English teaching methods which are appropriate for special learning law of English learners in China innovatively, improve quantity and quality of language information input, excavate college students' potential to learn English, cultivate their consciousness and habit about English application, strengthen their confidence in learning English well and enhance college students' ability to apply the second language flexibly. In accordance with current status of English teaching method in China, English teachers of colleges should update their educational concept continuously, think about which parts of current teaching methods should be improved, consider absorbing various kinds of advanced experience in English teaching of western developed countries, let English teaching of China accord SLA law to a larger extent and then make more contribution to sustainable development of China's English teaching.

\section{Reference:}

[1] Lei Zaixiu. Relationship between SLA theory and multimedia teaching of college English [J]. Journal of LanZhou University of Arts And Science (Social Sciences Edition), 2007(6).

[2] Chen Juan. On relationship between SLA theory and foreign language teaching [J]. Network Wealth, 2009(11).

[3] Zuo Xiuyuan. Exploration on relationship between language anxiety and SLA [J]. Journal of Liaoning Educational Administration Institute, 2010(6).

[4] Wang Lin. Exploration on application of SLA theory to college English teaching [J]. Journal of Beihua University (Social Sciences Edition), 2010(6).

[5] Xu Ziyan. Research on relationship between acquisition of English sports event expression and the second language level [J]. Foreign Language of China, 2013(5).

[6] Yang Guilan. Application of SLA theory to college English teaching [J]. Contemporary Communication, 2014(2). 